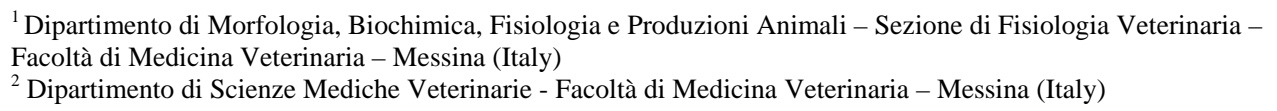

\title{
Preliminary investigation into thermal stress during diurnal road transportation of young ostriches (Struthio Camelus) (short communication)
}

\begin{abstract}
Diurnal road transportation influence on body temperature and on body weight was studied in 60 chick ostriches. Prior to the transportation, body temperature and body weight were recorded. On arrival, an elevation in body temperature and a decrease in body weight were observed. In particular, recording for body temperature were $39.34 \pm 0.16^{\circ} \mathrm{C}$ before the departure and $39.86 \pm 0.17^{\circ} \mathrm{C}$ at the arrival $(P<0.001)$; for body weight, recordings were $1.72 \pm 0.05 \mathrm{~kg}$ before the departure, $1.64 \pm 0.07 \mathrm{~kg}$ at the arrival and $1.6 \pm 0.08 \mathrm{~kg}$ after 1 day $(P<0.001)$. Only on the $4^{\text {th }}$ day after the arrival the body temperature and on the $2^{\text {nd }}$ to the $3^{\text {rd }}$ day the body weight reached the exit values before departure. Analysis of the effect of transportation on body temperature and body weight was conducted by factorial analyses of variance (ANOVAs). Obtained results show physical sign of stress with a high body temperature and a low growth rate of chicks probably due to the diurnal transportation.
\end{abstract}

Key Words: animal welfare, body weight, body temperature, stress transportation, Struthio Camelus

\section{Zusammenfassung}

Titel der Arbeit: Vorläufige Ergebnisse zum Wärmestress bei ganztägigem Straßentransport von jungen Straußen (Struthio camelus) (Kurzmitteilung)

Es wurde der Einfluss eines ganztägigen Straßentransportes auf die Körpertemperatur (BT) und das Körpergewicht (BW) an 60 Straußenküken im von 25 \pm 2 Tagen untersucht. Beide Merkmale wurden sowohl vor dem Abtransport als auch nach der Ankunft und bis zum 6. Tag erfasst. Nach der Ankunft wurde eine Erhöhung der BT und Verringerung des BW beobachtet. So erhöhte sich die BT von 39,34 $\pm 0,16$ auf $39,86 \pm 0,17^{\circ} \mathrm{C}$ $(P<0,001)$ und das BW sank von 1,72 $\pm 0,05$ auf 1,64 $\pm 0,07 \mathrm{~kg}(P<0,001)$. Der Einfluss des Transportes auf die untersuchten Merkmale wurde mittels faktorieller Varianzanalyse (ANOVA) geprüft. Die signifikante Merkmalsbeeinflussung deutet auf physischen Stress als Folge des ganztägigen Transportes der Tiere hin.

Schlüsselwörter: Körpergewicht, Körpertemperatur, Transportstress, Strauss, Struthio Camelus

\section{Introduction}

Ostrich farming has been well developed in South Africa for over a century and in the past few decades has become increasingly popular in several other countries, such as USA (DUEWER et al, 1994), Australia (HASTINGS and FARREL, 1991) and Italy (ENDRIGHI et al, 1996). Chicks are especially vulnerable during the first few weeks after hatching and frequently succumb to diseases, various disorders and stress (HUCHZERMEYER, 1994; SAMSON, 1997). Hyper- and hypothermia are stresses that potentially are not only a direct cause of mortality but can also predispose chicks to other ailments and make them susceptible to disease and infections (JENSEN et al, 1992): ostrich chicks are sensitive to temperature and are particularly susceptible to cold. After hatching, the normal body temperature, in birds, and particularly in ostrich 
chicks, is between $37.5^{\circ} \mathrm{C}$ and $38^{\circ} \mathrm{C}$ although immediately following hatching, whilst the down feathers are still wet, the body temperature may go down.

Ostrich chicks are unable to regulate their body temperature at hatch thus a necessity for an external source of heat (around $32-35^{\circ} \mathrm{C}$ ) although the need for supplement heat lessen as the animals grow. In the days following hatching there is a rise in the body temperature. This is particularly marked in the first week (LAMOREUX and HUTT, 1939; FREEMAN, 1971; BROWN and PRIOR, 1999) and there then follows a slower rise during the second and third weeks when the adult level is reached (LAMOREUX and HUTT, 1939; RANDALL, 1943). This rise is not progressive and several authors have noted a transient but significant fall in body temperature between the $4^{\text {th }}$ and $5^{\text {th }}$ days after hatching (FREEMAN, 1971) due, at least in part to an increase in the metabolically active mass of the bird without a concomitant increase in the total surface area (BALDWIN and KENDEIGH, 1932; FREEMAN, 1971) while RICKLEFS (1974) observed that chicks are capable of efficient thermoregulation within a few days of hatching. JENSEN et al. (1992) suggest that hypothermia is common during the first twelve weeks after hatching and that during this time chicks gradually homeothermic. Furthermore PERELMAN (1991, cited in JENSEN et al., 1992) suggests that chicks up to eight weeks of age are unable to thermoregulate.

When the temperature is below the thermoneutral zone, a thermoregulatory thermogenesis occurs in response to acute cold exposure. The purpose of regulatory thermogenesis is to increase heat production in cold to sustain body temperature despite increased heat loss. Regulatory thermogenesis can occur in muscle in the form of shivering thermogenesis, and in brown adipose tissue and possibly in some other tissues too as nonshivering thermogenesis. When chicks are exposed to high temperature, the only means available for remaining cool is evaporation. Since no bird has been shown to sweat it is assumed that most of his water is evaporated in the respiratory tract. The amount of water evaporated depends on ventilation and the difference in the water content of inspired and expired air. The normal respiratory rate of the ostrich is 4-7 breaths/min and when ambient temperature increases up to $25^{\circ} \mathrm{C}$ the rate rises to about 45 breaths/min (CRAWFORD and SCHMIDT-NIELSEN, 1967).

Thermoregulation is, however, energetically expensive and thermoregulatory behaviour such as huddling may compete with other important activities like feeding (BROWN and PRIOR, 1999), and may influence growth rate. Some authors (DEEMING et al, 1993) made observations on the growth, survival and sex ratio of the chicks hatched. The chicks decreased in weight for five days after hatching before they began a sustained period of exponential growth and the pattern of change in weight was applied as a useful indicator of the chicks' health. Ostrich farming has become increasingly popular in several countries and adult ostrich transportation has been studied by several authors (BURLINI, 1999; DE JONGE et al., 1997; PAYNE, 1993; PAYNE, 1994) and best vehicles are the horse trailer (BURLINI, 1999) or a modified cattle transporters divided into pens (PAYNE, 1993; PAYNE, 1994).

Given the lack of data about the transportation stress and the absence, in some countries, of welfare laws regulating the treatment of chicks ostriches, the purpose of our study is to evaluate body temperature as index of diurnal transportation stress and its influence on body weight in young ostriches taking into consideration their welfare 
during transportation and at their arrival according to the Council Directive 91/628/EEC of 19 November 1991.

\section{Materials and Methods}

360 African Black/Blue Neck chick ostriches aged 25 \pm 2 days and clinically healthy were transported in July in 36 chicken boxes $(90 \times 60 \times 30 \mathrm{~cm})$, with a stock density in the box higher than the one recommended in the Council Directive 91/628/EEC of 19 November 1991. The trip, of $950 \mathrm{~km}$ distance on a closed lorry with some windows on the top, lasted for 12 hours. Internal temperature and relative humidity were continuously recorded with a data logger (Gemini, Chichester, West Sussex, UK) placed in the middle of the lorry. During the trip the mean ambient temperature in the lorry was $31.07^{\circ} \mathrm{C}$, and the relative humidity oscillated in a non-systematic way between 75 and $85 \%$. Within the 360 subjects we chose 60 chicks (ten subjects from six boxes placed at the beginning, in the middle and at the end of the lorry) identified by means of a metacarpal ring. At the end of transportation ten chicks (one or two for each box) were dead. On this subjects a necroscopy was made with negative result. After the arrival animals were fed and the ambient temperature was thermostatically maintained at $22 \pm 2^{\circ} \mathrm{C}$ as recommended by ALLDREDGE (1993).

Body temperature was measured with a digital thermometer (model HI92704, Hanna Instruments, Bedfordshire, UK) whose probe was inserted $30 \mathrm{~mm}$ into the cloaca. Body temperature and body weight recordings were taken every day at 08.00 a.m. before feeding.

The chicks, stabled on chipboard and fed on lucerne and concentrates and water ad libitum, were monitored for body temperature and body weight at $08.30 \mathrm{~h}$ for six days. Analysis of the effect of transport on body temperature and body weight was conducted by factorial analyses of variance (ANOVAs) running a simple repeatedmeasures ANOVA for body temperature (for the assessment of temperature pattern) and for body weight (for the assessment of growth rate) comparing the means of the 8 time points. The two variables cannot be combined into a single factorial ANOVA because they involve different units of measurement.

\section{Results}

Record for ambient temperature and relative humidity are shown in Figure 1. Figure 2 shows mean values and standard errors of body temperature and body weight in chicks recorded at the departure, after the arrival and during the six days following the arrival. For the 50 subject included in the data, an average body temperature of $39.34 \pm 0.16^{\circ} \mathrm{C}$ and an average body weight of $1.72 \pm 0.05 \mathrm{~kg}$ were recorded before the departure while, after the arrival average body temperature was $39.86 \pm 0.17^{\circ} \mathrm{C}$ and average body weight was $1.64 \pm 0.07 \mathrm{~kg}$. The ANOVA for repeated measures of obtained data revealed a significant effect of transport on body temperature $\left(F_{7,343}=157.43, P<0.001\right)$ and on body weight $\left(F_{7,343}=133.34, P<0.001\right)$. At the arrival mean body temperature rose in average to $39.86^{\circ} \mathrm{C}$, which was significantly higher than the body temperature recorded at the departure while body weight decreased in average to $1.64 \mathrm{~kg}$, which was significantly lower than the body weight recorded at the departure. After the first day, body temperature start to decrease $(39.79 \pm 0.16)$ in a continuous way for the next six days and body weight increased in the same way restoring the species 
physiological values. Only on the $4^{\text {th }}$ day after the arrival the body temperature and on the $2^{\text {nd }}$ to the $3^{\text {rd }}$ day the body weight reached the exit values before departure.

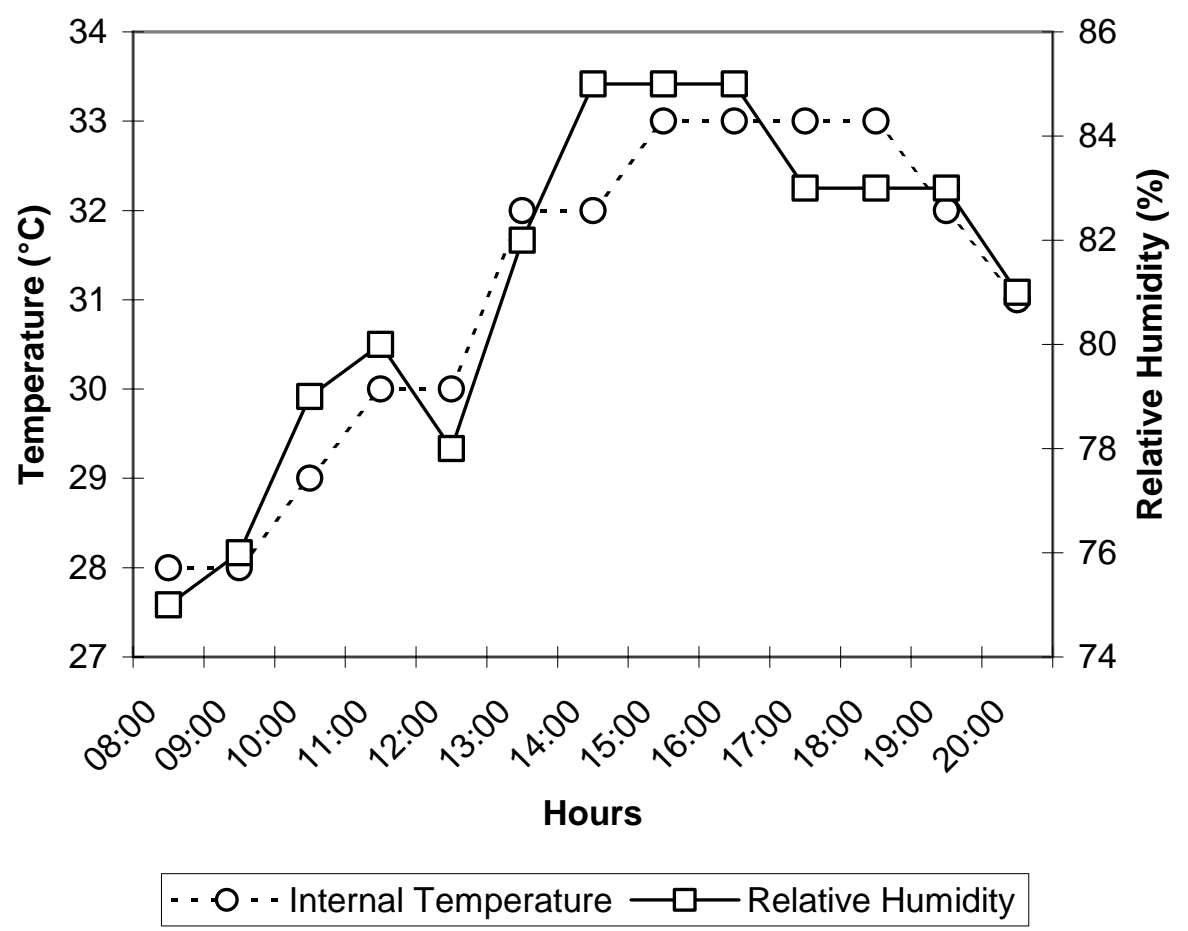

Fig. 1: Hourly values of ambient temperature $\left({ }^{\circ} \mathrm{C}\right)$ and internal relative humidity (\%) during the transport. (Stündliche Werte der Temperatur und der relativen Luftfeuchtigkeit während des Transportes im Transportfahrzeug)

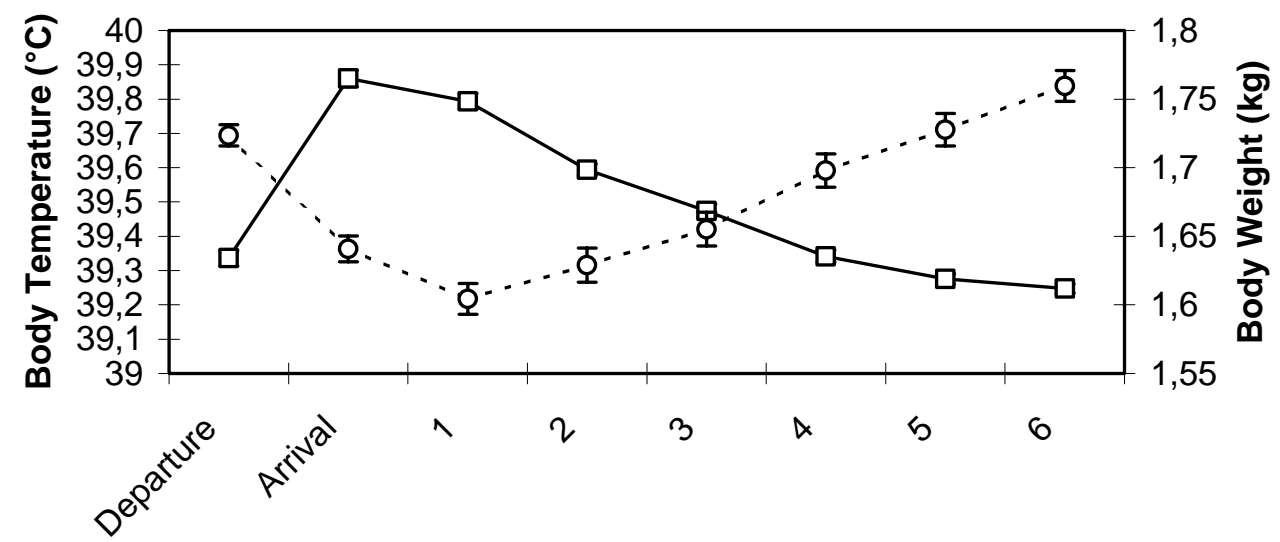

Days after the arrival

$\longrightarrow$-Body Temperature $\quad$ - - o - - - Body Weight

Fig. 2: Mean values \pm standard error (SE) of body temperature $\left({ }^{\circ} \mathrm{C}\right)$ and body weight $(\mathrm{kg})$ recorded in the different days (Mittelwerte und Standardfehler von Körpertemperatur und Körpergewicht während der Beobachtungstage)

\section{Discussion}

Ostriches are extremely prone to stress: chicks exposed to high intensity radiations without adequate access to shade or water quickly show signs of heat stress at even moderate temperature and chicks exposed to a combination of rain, wind and low 
temperature will almost certainly succumb to hypothermia (BROWN and PRIOR, 1999). Although young chicks can thermoregulate well under various environmental weather conditions, it must also be remembered that maintenance of body temperature incurs an energetic cost for small chicks: thermoregulatory behaviours like lying down and huddling at low temperature and panting, wing spreading and postural changes at high temperature may reduce thermoregulatory costs, these also compete with feeding activities, which may result in shorter feeding times and reduced growth rates (OSBALDISTON, 1996). Growth rate could be affected by ambient temperature. The optimal temperature for growth will decrease with an increase in age. In the 4-5 week rearing period the maximum weight gain will be achieved in the temperature range 10$22^{\circ} \mathrm{C}$. VAN KAMPEN (1981) showed that the metabolizable energy intake, which is equal to the difference in food and excreta energy, decreases progressively with increasing environmental temperature. WEISS et al. (1963) found that in the process of adaptation to hot environment there were reduction in body weight, respiratory rate, but an increase in tidal volume, heart rate and blood pressure. Reduced body weight is followed by a reduced feed intake. OZCELOK and OZBEY (2004) observed in Japanese quail that the value of laying performance were lower at $35^{\circ}$ than the ones at $18-24^{\circ} \mathrm{C}$ degree just like an effect on some blood parameters were found at these high temperature. Although the responses are reversed when the bird is adapted, the time taken to do this depends on the parameter that is being measured. HILLERMAN and WILSON (1955) showed that body temperature becomes constant after about 5 days. Furthermore, transport constitutes an inevitable source of stress (DE JONGE et al, 1997) for young ostriches. The increase in relative humidity during road transportation is caused by the increase of respiratory rate and thus to an increase of the water content in the lorry.

Our results show physical sign of stress in chicks like a mortality of $16.7 \%$ and an increase of body temperature of $0.52^{\circ} \mathrm{C}$ and a decrease of body weight of $0.12 \mathrm{~kg}$ during the two days after the arrival as a response to physical stress. This decrease can be explained because thermoregulation involves an energetic expenditure from the chicks; the increase in body temperature in fact, causes a decrease in food intake as result of mechanisms of thermodispersion.

From the fourth day after the arrival body temperature decreases (because the hyperthermia that was established during the transportation) while starting from the second to the third day after the arrival body weight increases thus restoring the species physiological values.

Given that ostrich farming, and thus their transportation, has become increasingly popular in several countries, on the basis of our knowledge of the ostriches' thermoregulatory mechanism we can state that transportation of young ostriches is apparently stressful because, in this particular group of ostriches, there was an elevation in body temperature for several days and a short lowering in body weight as a result of thermoregulatory response. Ostriches are more severely affect by hot weather (REINER et al, 1996) and chicks are very sensitive to overcrowding, overheating and poor ventilation (WOTTON and HEWITT, 1999) thus the stress transportation could be prevented by transporting chicks during night time (BURLINI, 1999) on closed vehicles with active ventilation to control the thermal environment. Such vehicles can maintain low light levels which will calm the birds and will insulate 
them from external noise and visual images (PAYNE, 1993; PAYNE, 1994). Further investigation, however, are needed to confirm this hypothesis.

\section{ALLDREDGE, B.E.:}

\section{References}

Chick rearing. In: Bryden D.I. (ed), Proceedings of the meeting of the Australian Ostrich Association, Inc (Vic) 2171 (Sydney, Postgraduate Committee in Veterinary Science, University of Sydney) (1993), 145-146

BALDWIN, S.P.; KENDEIGH, S.C.:

Publications of the Cleveland Museum of Natural History, (Cleveland, Ohio) (1932)

BROWN, C.R.; PRIOR, S.A.:

BURLINI, F.:

Development of body temperature regulation in ostrich chick. Br. Poult. Sci., 40 (1999) 4, 529-535

Ostriches transportation (Italian). In: Papi (Ed).Proceeding of EOA World Congress (1999)

CRAWFORD, E.C., SCHMIDT-NIELSEN, K.:

Temperature regulation and evaporative cooling in the ostrich. Am. J. Physiol., 212 (1967 ) 2, 347-353

DEEMING, D.C.; AYRES, L.; AYRES, F.J.:

Observations on the commercial production of ostrich (Struthio camelus) in the United Kingdom: rearing of chicks. Vet. Rec., 132 (1993) 25, 627-631

DE JONGE, G.; LEIPOLDT, A.L.; MIDDELKOOP, G.J.H.:

Health and welfare of ostriches in the Netherlands. PP-uitgave PP-Beekbergen, the Netherlands (1997), 58

DUEWER, L.; MADISON, M.; CHRISTENSEN, L.:

The exotic sector: ostriches and emus. Agricul. Outlook, AO 208 (1994), 15-17

ENDRIGHI, E.; BIANCHI, A.; ZUCCHI. G.:

Ostrich farming, conditions for a future. Rivista di Avicoltura, 65 (1996), 16-22

FREEMAN, B.M.:

Physiology and biochemistry of the domestic fowl. In: Bell D.J. and Freeman B.M. (eds) Academic Press: London, New York (1971)

HASTINGS, M.Y.; FARREL, D.J.:

A history of ostrich farming - its potential in Australian agriculture. Recent Advances in Animal Nutrition in Australia (1991), 292-297

HILLERMAN, J.P.; WILSON, W.O.:

Acclimatization of adult chickens to environmental temperature changes. Am. J. Physiol., 180 (1955), 591-595

HUCHZERMEYER, F.W.:

Multifactorial diseases of young ostriches. Vet. Med., 7 (1994), 115-118

JENSEN, J.M.; JOHNSON, J.H.; WEINER, S. T.:

Husbandry and medical management of ostriches, rheas and emus. Texas, Wildlife and Exotic Animal Teleconsultants (1992)

LAMOREUX, W.F.; HUTT, F.B.:

Variability of body temperature in the normal chick. Poult. Sci., 18 (1939), 70-75

OSBALDISTON, G. W.:

The response of the immature chicken to ambient temperature. In: Horton-Smith C. and Amoroso E.C. (ed.) Physiology of the Domestic Fowl. Oliver and Boyd Edinburgh (1996), 228-234

OZCELOK, M.; OZBEY, O.:

The effect of the high environmental temperature on some blood parameters and the laying performance

PAYNE, H.: of Japanese quails with different body weights. Arch. Tierz., Dummerstorf 47 (2004) 1, 93-98

PAYNE, H.:

Welfare of ostriches and other ratites during transport. St. Vet. J., 3 (1993), 8-18

Welfare of ostriches and other ratites during transport. Live Animal Trade and Transport Magazine, September (1994), 45-48

RANDALL, W.C.:

Factors influencing the temperature regulation of birds. Am. J. Physiol., 139 (1943), 56-63

REINER, G., SEITZ K., DZAPO, V.:

A survey of farming environment and ostrich behaviour in Germany. In: Deeming D.C. (ed) Improoving our understanding of Ratites in a farming environment. Oxfordshire, Ratite Conference (1996)

RICKLEFS, R.E.: 
Energetics of reproduction in birds. In: Paynter R A (ed.) Avian Energetics. Publication of the Nutthall Ornithological Club (1974), 152-292

SAMSON, J.:

Prevalent diseases of ostrich chicks farmed in Canada. Can. Vet. J., 38 (1997), 425-428

VAN KAMPEN, M.:

Thermal influences on poultry. In: Clark J.A. (ed) Environmental aspects of housing for animal production. Butterworths, London (1981), 131-147

WEISS, H.S., FRANKEL, H., HOLLANDS, K.G.:

The effect of extended exposure to a hot environment on the response of the chicken to hyperthermia. Can. J. Biochem. Physiol., 41 (1963), 805-815

WOTTON, S.B., HEWITT, L.:

Transportation of ostriches - a review. Vet. Rec., 145 (1999), 721-731

Received: 2004-07-12

Accepted: 2005-03-07

Authors' addresses

Prof GIUSEPPE PICCIONE*, Dr ANNA COSTA, Prof GIOVANNI CAOLA

Dipartimento di Morfologia, Biochimica, Fisiologia e Produzioni Animali - Sezione

di Fisiologia Veterinaria - Facoltà di Medicina Veterinaria

Polo Universitario dell'Annunziata

98168 Messina / Italy

Prof ELISABETTA GIUDICE

Dipartimento di Scienze Mediche Veterinarie - Facoltà di Medicina Veterinaria

Polo Universitario dell'Annunziata

98168 Messina / Italy

*Corresponding author

E-mail: Giuseppe.Piccione@unime.it 